Article

\title{
Two Faces of the Manchu Shaman: "Participatory Observation" in Western and Chinese Contexts
}

\section{Feng Qu}

Arctic Studies Center, Liaocheng University, 1 Hunan Road, Dongchangfu District, Liaocheng 252000, China; alaskafengziqu@163.com

Received: 25 October 2018; Accepted: 23 November 2018; Published: 26 November 2018

check for updates

\begin{abstract}
Russian anthropologist Shirokogoroff and Chinese ethnographers have provided different understandings of Manchu shamanism. The former approach is centered in the psychological dimension based on the Western context while the latter approach focuses on the ritual and sacrificial systems based on a non-Western Chinese context. However, an in-depth analysis of Chinese ethnographic writings shows that the Chinese context also embodies aspects of existing Western concepts. Due to the fact that both approaches have problems in writing cultures, the author suggests that a constructive dialogue between the Western experience and Chinese experience should be conducted in reconstruction of shamanism theories.
\end{abstract}

Keywords: Shirokogoroff; Western context; "non-Western" Chinese context; Manchu shamanism

The pioneering research of Manchu shamanism of North China is actually not from a Chinese scholar, but from the Russian anthropologist Sergei Mikhailovich Shirokogoroff (1887-1939). His fieldwork and research among Manchus was conducted in the early 1920s and is included in his influential monograph Psychomental Complex of the Tungus (Shirokogoroff 1935). For Chinese scholars, the systematic fieldwork and integrative studies of Manchu shamanism were beginning in the 1980s, sixty years later than Shirokogoroff.

The Manchu was historically the largest group among Tungusic speaking peoples to inhabit the Asian subarctic region, which today covers modern Russian Siberia and Northeast China. Apart from the Manchus, a number of other Tungusic speaking ethnic groups such as the Oroqen, Evenki, Even, and Nanai were known from this wide region. Historical evidence indicates that the Manchu was descended from a Jurchen speaking group who came to prominence during the Ming Dynasty (1368-1644). The Manchu became a powerful military force, ultimately founding China's last imperial Qing Dynasty (1644-1912). The assent to power in Northern China of the Manchu, began in a period prior to Mongolian Yuan (1271-1368) and later Ming Dynasty (1368-1644). The Jurchen established their own Jin Dynasty (1115-1234) which controlled the North China (Jin and Zhang 1992; Sun and Sun 2010). The Manchu, as well as their Jurchen ancestors, practiced shamanism for many centuries previously (Elliott 2001; and Roski 1998). This tradition continued during the post imperial period until 1949 and revived at the end of the 1970s.

Surprisingly, while Shirokogoroff has remained profoundly influential on Western shamanism studies, especially after 1960s until today (Znamenski 2007, p. 107), he has less influence on Chinese scholarship, though his work has been occasionally cited. At the end of 1970s, China ended the Cultural Revolution and the research on shamanism was not subject to political restrictions any more. Since then, especially after the 1980s, many research projects of Manchu shamans have been conducted and numerous academic articles and monographs have been published in Chinese (e.g., Fu 1990; Fu and Meng 1991; Guo 2001; Shi and Liu 1992; Song 1993; Song and Meng 1997; Wang 2002; and Yu et al. 2014). The method of fieldwork used by Chinese scholars is certainly the so-called "participatory observation" and this qualitative research approach does not differ significantly from 
Shirokogoroff's sixty years ago. However, Chinese scholars have totally different understandings of Manchu shamanism from Shirokogoroff's approaches. First, the sacrificial rite is viewed as the central feature of Manchu shamanism in Chinese literature. However, for Shirokogoroff (1935), the Manchu shamanism is characterized by the shaman's ecstatic technique and psychological elements. Second, although Chinese scholars have distinguished the ecstatic shaman from the non-ecstatic "domestic shaman" or "clan shaman" who serve his community as a ritual officiant without using trance, both types of ritualists are defined and conceptualized as the shaman. However, Shirokogoroff uses trance as a crucial criterion to determine the genuineness of the shaman and only places the ecstatic ritualist in the category of the shaman.

My analyses in this paper suggest that the different approaches to Manchu shamans between Shirokogoroff and Chinese ethnographers are determined by the different social contexts which scholars are situated in and upon which they relied. The term "West context" in this paper refers to two aspects. The first aspect is Western consciousness based on the elements of romance, imaginations, and discovery in ethnographic writings. As Said $(1978$, p. 8 ) has noted, "The imaginative examination of things Oriental was based more or less exclusively upon a sovereign Western consciousness." George Marcus and Michael Fischer have criticized Western ethnography because it is always tied to "the dominant historic narrative motifs" and the "romantic discovery motif" (Marcus and Fischer 1986, p. 24). The second aspect is colonialist consciousness which dominated the early anthropological construction based on the Western hegemony. In this way, ethnography always represents a text written "by the dominant about the weak" (Layton 1997, p. 213). The textual authority is thus achieved in three dimensions: Establishing a narrative presence, envisioning a textual organization, and pre-encoding the presentation of data (Marcus and Cushman 1982, p. 39). Shirokogoroff is a West-trained scholar, who had studied philosophy and anthropology in France and St Petersburg (see Boekhoven 2011, p. 93; Znamenski 2007, pp. 107-8). In this paper, I argue that the Western social context laid by Shirokogoroff as a prominent feature of this fields academic foundations, when he was working on Tungus and Manchu studies.

In contrast, such a Western context has less influenced on Chinese scholars, whether in their field research or in their ethnographic writings. The non-Western experiences have led Chinese ethnographers to their writings as what Geertz has called "from native's point of view" (Geertz 1983, pp. 55-70). Therefore, I use the term "Chinese non-Western context" to refer to social and theoretical trends in China, which has shaped Chinese ethnographers' writings.

Yet, the deep explorations of Chinese ethnographic writings reveal that the non-Western Chinese context is not really non-Western. The social context engaged with political and intellectual powers also dominate Chinese ethnographic writings of shamanic cultures. In this way, both Western context and "non-Western" Chinese context are problematic. Therefore, a two-way dialogue between Western experience and Chinese experience is suggested in the reconstruction of Shamanism theories.

\section{Shirokogoroff's Approach and the Western Context}

When looking back to Psychomental Complex of the Tungus today, it is not difficult for us to find out that Shirokogoroff was actually among the first to challenge the Western tradition of the Enlightenment positivism or science and the Eurocentric trend, which "threatened anthropologists no matter which direction they went" (Znamenski 2007, pp. 107-8). Using the term "psychomental complex", he attempts to stress "psychic and mental reactions" on the general cultural milieu, which consists of material culture and social organization to form "a certain system" along with psychomental elements (Shirokogoroff 1935, p. 1). He completely moved away from the evolutionism and adopted functionalist and psychological theories from Malinowski, combining Boas' relativism to form his "own ethnographic complex" (Boekhoven 2011, p. 94). Such a psychomental complex, in Shirokogoroff's assumption, acted "as a function of adaptation to the variable milieus" (Shirokogoroff 1935, p. 1) and "was rooted in organic life and human biology" (Znamenski 2007, p. 108). 
Generally and traditionally, the shamanic sacrificial rites among Manchus can be divided into two categories: The domestic sacrifice (or household sacrifice) and the wild sacrifice. The domestic sacrifice worship the Heaven and ancestral spirits and the clan's protective deities (they are called domestic spirits or clan spirits), while the wild sacrifice involves animal and human heroic spirits (they are called wild spirits). The ritual specialists who carry on domestic rites are called p'oyun saman or booimukun saman in Manchu (meaning clan shaman) and jia saman 家萨满 in Chinese (meaning domestic, household shaman or clan shaman). The specialists providing service for the wild sacrifice is called amba saman in Manchu (meaning great shaman or master shaman) and ye saman 野萨满 in Chinese (meaning wild shaman) (see Fu and Meng 1991; Song 1993; and Shirokogoroff 1935). A clan that only keeps the domestic sacrifice usually has several clan shamans. However, only one chief shaman (ta saman in Manchu) is among them. A clan which remains the wild sacrifice only has one amba saman, but also has a few numbers of assistants (jari in Manchu and zaili 栽立in Chinese) who are required to communicate with the spiritual beings abiding the shaman's body during a séance. The clans providing the wild sacrifice service also carry on the domestic sacrifice. The domestic sacrifice which does not need trance is usually conducted by those assistants, and thus they may also function as clan shamans. A new clan shaman and an amba shaman's assistant are elected through the clan meeting. However, the amba shaman is usually chosen by the spirit of an ancestral shaman (Fu and Meng 1991; Song 1993; and Shirokogoroff 1935).

For Shirokogoroff, a genuine shaman must possess the ability to fall into an ecstasy and must act as the master of spirits. As he points out (Shirokogoroff 1935, p. 274), the essential characteristics of shamanism include:

(1) The shaman is a master of spirits; (2) he has a group of mastered spirits; (3) there is a complex of methods and paraphernalia recognized and transmitted; (4) there is a theoretical justification of the practice; (5) the shamans assume a special social position.

While the Manchu clan shaman meets all other characteristics with the exception of the first two, in Shirokogoroff's view, these specialists are "shamans only by name" and thus should be considered as "priests" rather than shamans (Shirokogoroff 1935, p. 145). He writes,

Here I had in view the shamans which in Manchu are shamans only by name. The complexity of the theory of spirits, and the existence of elaborated rituals and prayers, also the need of regulating activity of the ancestors-spirits have imposed establishment of specialists who are in charge of looking after and managing these spirits. As a matter of fact, they are nothing else but "clan priests" who are either elected by the clan, or merely appointed by the clan authorities (mokunda and clan meetings)... In Manchu they are called p'oyun saman, i.e., home ("family," "clan") shamans. They greatly differ from ordinary saman-"the shaman", for they do not introduce themselves the spirits and they do not "master" spirits.

Shirokogoroff's trance-centered definition of the term shaman was popularized by Mircea Eliade (1907-1986) in his masterpiece Shamanism: Archaic Techniques of Ecstasy (Eliade 1964), although both authors actually have very different understandings of the term "ecstasy." For Shirokogoroff, shamanic ecstasy or trance mostly refers to the shaman's controlling of spirits and being possessed by spirits at will (Shirokogoroff 1935) ${ }^{1}$. In contrast, Eliade argues that the shaman's ecstasy means the soul flight rather than spirit possession (Eliade 1964). Moreover, one more debate between two scholars is if shamanism is an archaic phenomenon. For Shirokogoroff, shamanism "is a relatively recent phenomenon which seems to have spread from the west to the east and from the south

1 Shirokogoroff (1935) writes, the Tungus shaman "refers to persons of both sexes who have mastered spirits, who at their will can introduce these spirits into themselves and use their power over the spirits in their own interests, particularly helping other people, who suffer from the spirits; in such a capacity they may possess a complex of special methods for dealing with the spirits." 
to the north" and possibly developed from Buddhism introduced by the Mongols, Manchus, and Chinese (Mironov and Shirokogoroff 1924, p. 127 and Boekhoven 2011, p. 96). Moving away from evolutionism, he bluntly states that "shamanism is not an initial complex in a chain of an 'evolving' process, but a complex of secondary formation" (Shirokogoroff 1935, p. 276). In contrast, Eliade is more inclined to believe that shamanism is an archaic magico-religious phenomenon for humankind in most parts of the world (Eliade 1964). In Znamenski's words, Eliade "approached shamanism as archaic, primal spirituality that sprang up independently among all peoples at the dawn of their history and that allowed them to maintain direct contact with the sacred" (Znamenski 2007, p. 171). Additionally, Shirokogoroff treats shamanism as an ethnographical phenomenon practiced only "among the Tungus and Manchus" (Shirokogoroff 1935, p. 275). However, his ecstasy-centered definition of shamanism was adopted by later scholars such as Hultkrantz (1973), Lewis (1971), and Harner (1980), along with Eliade (1964), as a popular model for a definition of a worldwide universal phenomenon.

The trance model has remained as a mainstream in shamanism studies since the 1960s until today. It is undeniable that both Shirokogoroff and Eliade are responsible for this academic trend, which has dominated the theoretical debates in shamanism on the second half of the twentieth century. However, in recent decades, anthropologists have started to question the universal rule and the biological nature of the trance model, which downplay social and historical context and thus fail to provide an in-depth understanding of magico-religious phenomenon in a particular culture (Astor-Aguilera 2014; Gibson 1997; Hutton 2001; Kehoe 1996, 2000; Klein et al. 2002; Pedersen 2007; Sidky 2010; and Wallis 2009, 2013). As Wallis (2013, p. 313) has pointed out, the trance theory "universalizes shamanism" and "neglects the wider ontological and epistemological positioning of shamans and their art." Sidky (2010, p. 223) notes that, when shamanism has been treated as a timeless and ahistorical phenomenon reflected by human central nervous system, the ethnographic and historical materials have been regarded as "superfluous" to shamanism study.

Znamenski (2007, p. 171) has realized that the Eliade's shamanism book is "an impressionistic and romantic treatise." I believe that this comment also fits Shirokogoroff's writings. According to George Marcus' and Michael Fischer's analysis (Marcus and Fischer 1986, p. 24), modern ethnographic writings as a genre have similarities with early traveler and explorer accounts. The primary common feature between the two genres is that both encompass "some of this sense of romance and discovery." Thus the ethnographic narratives no longer serve well enough to reflect the world in which anthropologists observed in the field. In this way, Marcus and Cushman (1982, p. 29) borrow the concept "realism" from the literary theory of nineteenth century to call the ethnographical writings "ethnographic realism" and state that this is "a mode of writing that seeks to represent the reality of a whole world or form of life." During their "interpreting" of native concepts into Western languages for the readers, anthropologists established their authority largely through three constructive ways: Establishing a narrative presence, envisioning a textual organization, and pre-encoding the presentation of data (Marcus and Cushman 1982, p. 38-46). The ethnographic realism as the holistic representation of other ways of life is a particular kind of realism because it was "tied to the dominant historic narrative motifs" (Marcus and Fischer 1986, p. 24).

Robert Layton has revealed that anthropologists always have the power to choose one translation of the native culture rather than another, because ethnography "has usually been written by the dominant about the weak, and the practice of translation confers power." Using this power, anthropologists choose "what to render meaningful or rational" about the native others (Layton 1997, p. 213). There are no neutral theories. Theories are always chosen for a purpose, "to draw our own attention, and that of our readers, to aspects of social life and to propose causal connections between events" (Layton 1997, p. 215). That is to say, the power for ethnographic writings is based on Western imaginations of the non-Western native cultures. Said (1935-2003) argues that the Western orientalism had been built "within the umbrella of Western hegemony" and on the "positional superiority" (Said 1978, p. 7) and "the imaginative examination of thongs Oriental was based more or less exclusively upon a sovereign Western consciousness" (Said 1978, p. 8). 
Hutton (2001) has found out that Western imaginations have run through the whole history of ethnographic writings of the Siberian shamans. Indeed, Shirokogoroff very much warned against the Eurocentric trend and "pre-existing theoretical conceptions" (Boekhoven 2011, p. 95) celebrated by anthropologists in his time, such as animism, evolutionism, primitivism, and mysticism (Shirokogoroff 1935, pp. 6-10). However, his "psychomental complex" and functionalism adopted from Malinowski are also a kind of pre-existing concepts derived from the European complex. In this way, his approach does not differ from other early ethnographic writers and is actually from the Western consciousness or Western context rather than "from native's point of view" (Geertz 1983, p. 55).

Different from Shirokogoroff who spent many years in the field among Siberian Tungus and Manchus in China, Eliade's shamanism research relied entirely on secondary sources, including both traveler accounts and early ethnographic writings. Without critical thinking of his data and inattentive to the romantic elements embedded in the materials, he formulated his trance model "by assembling bits and pieces of information from accounts of separate groups in Siberia" (Sidky 2010, p. 229)2. As a matter of fact, Eliade relied on Western imaginations of Siberian shamans to create the second layer of imaginations. Without any doubt, Shirokogoroff is among the most important sources of inspiration for Eliade's ecstasy theory (Eliade 1964). From Shirokogoroff to Eliade and afterwards, the human central nervous system has been centered in the mainstream of shamanism studies and the cultural, temporal, and geographic contexts have almost entirely been dismissed. In Sidky's words (Sidky 2010, p. 232), this academic stream "produces a category that is so vague as to be theoretically useless."

\section{Chinese Scholars' Approach and the Non-Western Context}

The earliest field research of Chinese Tungus was conducted by Chinese anthropologist Ling Chunsheng 凌纯声 in the 1930s among the Hezhe people (Ling 1990). The systematic fieldwork and integrated research of Manchu shamanism began in the 1980s when shamanic practices were revived among Manchus and other minorities in the north China. The best-known leading scholar in Manchu shamanism studies is Fu Yuguang 富育光, followed by Shi Guangwei 石光伟 (1934-1998), Song Heping 宋和平, Meng Huiying 孟慧英, Wang Honggang 王宏刚, Guo shuyun 郭淑云, and others. These scholars are never trained in the Western anthropological discipline. They received their degrees from academic institutes teaching Chinese Language and Literature (such as Fu, Meng, and Wang), Minorities Languages (such as Song), or History (such as Guo). For this reason, they seem to have received less influence from the Western context in their ethnographic writings.

It is worth noting that both Fu and Shi are native Manchu scholars. Fu was born in 1933 in a traditional Manchu-speaking family of Fucha Clan in Aihui, Heilongjiang Province, a border area to Russia. He is one of a few scholars who are skilled in Machu speaking and reading. As a village primary school teacher, his father Fuchaxilu Boyan 富察希陆.伯严 spent his whole life to have recorded numerous Manchu folklores, myths, and living shamanic practices and rituals. These valuable manuscripts have had significant influence not only to Fu Yuguang, but also to other scholars such as Song, Meng, Wang, and Guo ${ }^{3}$. During his childhood, he was an active participant in the Manchu Spring and Autumn Sacrifices. After graduating from the Department of Chinese Language and Literature of Northeast People's University (today's Jilin University) in 1958, he spent many years with Jilin Daily as a newspaper reporter. His ethnographic career actually began at the end of the 1970s when he took up an academic position in the Jilin Provincial Academy of Social Science (Fu 2015, pp. 93-95). In the 1980s and 1990s, collaborating with Shi, Wang, Meng, and Guo, he conducted field research among Manchus and other Chinese Tungus and published numerous monographs on shamanism and

2 Hutton (2001, p. 122) also pints out, “For the most part," Eliade "highlighted materials which supported his arguments, and disposed of the rest."

3 One of Fuchaxilu Boyan's documents has been edited by Fu Yuguang and Guo and published in 2017 (Fuchaxilu 2017). 
Manchu folklores (e.g., Fu (1990, 2000, 2005, 2009, 2014, 2015); Fu and Guo 2005; Fu and Meng 1991; and $\mathrm{Fu}$ and Wang 1995), along with over one hundred journal articles.

Shi is also a native Manchu scholar, born in the Shi clan in Jiutai county, Jilin province. What is important is that shamanism is still practiced today among Shi clan Manchus. According to my field note (30 April 2018 with He Xinsheng 何新生 and the Shaman Shi Guanghua 石光华), Shi Guangwei's Uncle Shi Qingshan 石清山 (his father's elder brother) was a master shaman of the clan. Different from other shamanism scholars, Shi is a trained music expert and received his degree from Shenyang Music College in 1961. His research hence focused on ritual music, drumming, chanting, and prayers (Shi et al. 2003; and Shi and Liu 1992).

Here, to my mind, the distinction between Shirokogoroff and Chinese scholars in writing the Manchu culture can be probably explained with Clifford Geertz's experience-distant/experience-near model (Geertz 1983). Geertz writes (Geertz 1983, p. 57),

An experience-near concept is, roughly, one that someone-a patient, a subject, in our case an informant-might himself naturally and effortlessly use to define what he or his fellows see, feel, think, imagine, and so on, and which he would readily understand when similarly applied by others. An experience-distant concept is one that specialists of one sort or another-an analyst, an experimenter, an ethnographer, even a priest or an ideologist-employ to forward their scientific, philosophical, or practical aims.

Shirokogoroff's ethnographic writing more likely fits the Geertz's experience-distant concept. As an analyst and an ethnographer, he developed his own scientific method to interpret Siberian and Manchurian natives for his English-spoken readers in Europe and North America. While he abandoned evolutionary ideas, his psychomental approach evidently follows the positivist tradition, which encompasses elements of romance and discovery. In contrast, Chinese scholars such as Fu and Shi are observers to over-serve their own culture. Though Manchu clans use Manchu as ritual language, their daily language is Chinese. Fu and Shi both are skilled in Manchu language; they interviewed informants in Chines and wrote in Chinese for Chinese readers. They are actually insiders of the culture rather than outsiders from the distant world. They have no aim to provide a scientific approach based on the positivist tradition like a West-trained scientist. Rather, they more focus on what they see, feel, think, and imagine. All these traits seem to correspond with the experience-near concept. Rather than discovering the other cultures, Chinese scholars attempt to reveal their local knowledge based on "the native's point of view" (Geertz 1983, p. 55). If we see the writers' own culture as subjectivity but the culture observed as objectivity, the producing process of Western ethnographic writings appears to be from subjectivity to objectivity and then back to subjectivity. However, this formula does not fit the producing process of Chinese ethnographic writings of the Manchu culture, because the border between subjectivity and objectivity for Chinese scholars is blurred. The context of Chinese writings is likely a mixture of subjectivity and objectivity. There is no dividing between the two domains. Such a context without the dominance of Western consciousness is called "Chinese non-Western context" in this paper.

In Chinese scholars' writings, Manuch shamanism is centered with sacrificial rites ${ }^{4}$. These rites can be generally divided into two categories: The domestic rites and the wild rites. According to Fu and Meng (1991, pp. 66-95), the domestic rites include regular or seasonal sacrifices, public rites, huanyuan 还愿 (a Chinese word, means returning the promise) rituals, and xupu 续谱 (compiling or editing the clan genealogy) rites. The most prominent seasonal rites are the Grand Spring sacrifice and the Grand Autumn sacrifice, usually hosted by a family but open for the whole clan members. Pubic rites are held when the clan successfully overcomes the occasional misfortune events such as flood, fire disaster, earthquake, and epidemics to give thanks to ancestors and other spirits for their

4 The Manchu rites are usually called shaoxiang 烧香in Chinese. The word shaoxiang means burning incense. The shaman's performance is called tiaoshen 跳神in Chinese. The word tiaoshen means jumping spirit. 
protection and blessing ${ }^{5}$. The shaman conducts the huanyuan ritual for a family after it has finally has conquered the occasional misfortune. The xupu sacrifice is analogous to the public rite and performed by the whole clan members. Song's classification (Song 1993, p. 11) is slightly different. She argues that the Manchu sacrificial rites generally consist of the public rites, the autumn thanks-giving sacrifices, huanyuan rituals, and the seasonal rites. All these rites can be performed either in domestic ritual style or in wild ritual style, and either on a regular basis or as occasionally required.

Surprisingly, all these Manchu rites and sacrifices are recorded in Shirokogoroff's work in details. The differences between the domestic and wild rituals have been summarized by both Shirokogoroff and Chinese scholars (Fu and Meng 1991; Song 1993; Shi and Liu 1992; and Shirokogoroff 1935). According to (Song 1993, p. 10; and Song and Meng 1997, pp. 73-74), three differences are most salient. First, deities and spirits involved are different. The domestic sacrifice worship Heaven and ancestral spirits and the clan's protective deities (they are called domestic spirits or clan spirits), while the wild sacrifice involves animal and human heroic spirits (they are called wild spirits). Second, the domestic sacrifice does not need ecstasy performed by the shaman, but the inspirational performance is used in the wild sacrifice. Ancestral spirits are invited by the shaman's chanting and dancing, a vital aspect of the ceremony is when they receive offerings in the ritual, while the spirits in the wild sacrifice descend to the rite through possessing the shaman's body and communicate with the shaman's assistants and the community. Third, the dancing and chanting are more formalized and the paraphernalia are relatively simpler in the domestic sacrifice than those in the wild sacrifice. However, two types of rites share many common features, such as being equipped with particular paraphernalia, chanting, drumming, praying, using food offerings and animal sacrifices, and having all clan members to participate in the ceremonies. In Chinese scholars' approach, both types of rites are in the category of Manchu shamanism and both the clan shaman and the amba shaman are shamans according to Manchu own language (Fu 1990; Fu and Meng 1991; Guo 2001; Shi and Liu 1992; Song 1993; Song and Meng 1997; and Wang 2002).

According to Shi'a and Liu's record (Shi and Liu 1992), a regular Manchu rite lasts from three to eight days and consists of three rituals: the first day's tiaojiashen 跳大神 (performing the domestic ritual) conducted by the clan shaman, the following several days' fangdasheng 放大神 (performing the wild ritual) conducted by the amba shaman, and the last day's jitainshen (carrying on sacrifices to the heaven) performed by the clan shaman again. All these three rituals constitute an overall shamanic sacrificial event and there is no need to consider one ritual shamanic and the other un-shamanic. However, the wild ritual was strictly banned by the Hongtaiji Emperor (1592-1643; r. 1627-1643) and the restrictions caused the declining of wild rituals throughout the Qing period (Jiang 2016). While the non-inspirational domestic rituals were practiced among Manchu clans, the wild shamanism survived in the remote areas of Manchuria and is even alive today. According to fieldwork in the 1980s, there were roughly over ten Manchu clans in Jilin and Heilongjiang Provinces who were practicing wild rituals (Fu and Meng 1991, pp. 85-86). Shirokogoroff emphasizes that Manchu domestic shamanism and the domestic shaman "appeared at a rather late period," namely, "only during the eighteenth century" (Shirokogoroff 1935, p. 341). However, Chinese scholars argue that the domestic sacrifice had been a long-standing ritual form and existed before the time of the formation of Manchu state. The domestic and wild rituals were originally embraced in one religious and spiritual complex (Fu and Meng 1991, p. 67; and Song and Meng 1997, p. 104).

\section{Non-Western Context or “Non-Western" Context?}

Nevertheless, if we admit that the Chinese writings of Manchu culture never go beyond the genre of the ethnographic writing, we must note that these writings, more or less, are still governed by the

5 Song (1993, p. 11) has added that the sacrifice to celebrate apprentices successfully graduated from the shaman career training is categorized in the class of the Public rite. 
relation between writers and world observed. This is to say, Chinese scholars' writings also reflect the way in which the weak is written by the dominant, because the practice of ethnographic research "confers power" (Layton 1997, p. 213). Such powers allow anthropologists to rely on the social context to produce knowledge for readers who are associated with the same context.

However, like the Western context, the Chinese non-Western context also consists of political, intellectual, and cultural powers. Surprisingly, my scrutiny of Chinese ethnographic writings shows that the Chinese context is not really non-Western. In Marxist and Communist China, the social evolutionism is regarded as a foundational theory to support its polity. The evolutionary trend was especially popular in the studies of history and anthropology in the 1980s and 1990s. The Chinese "non-Western" context has thus formed a powerful and unchallengeable narrative hegemony and knowledge system to have dominated the Chinese scholars' ethnographic writings. Pre-existing concepts, such as primitive culture, primitive religion, matriarchal society, animism, and totemism are common in the Chinese writings of Manchu shamanism. Fu (2000, p. 124), for example, writes, "Shamanism is a remnant of the primitive culture." Shi and Liu (1992, p. 1) write, "Tiaoshen performed in the shaoxiao ceremonies is the central element of Manchu shamanic rites, exhibiting many vivid and distinct phenomena of primitive cultures. Therefore, many scholars see shamanism as a 'living fossil' of ancient human societies." Wang (2002, p. 15) writes that "Manchu shamanism takes animism as the primary thinking. Based on this thinking, its beliefs and ideologies are very complicated and various." It is not difficult to identify that these narratives reflect Edward Tylor's (1832-1917) primitivism (Tylor 1924).

Inspired by Lewis Morgan's (1818-1881) theory (Morgan 1887), Chinese scholars have connected the matriarchy model with shamanism. Fu and Meng (1991, p. 273) write, "As a religious form, shamanism is centered in East Asia and North Asia. It was produced during the boom of the primitive matriarchal society and has lasted until today while has been declining." Wang writes, "Shamanism was produced during the matriarchal clan society. Its birth, formation, development, and evolution have experienced long history." Guo (2001, p. 1) writes, "The shamanic culture belongs to the domain of primitive cultures. Shamanism is a primitive, natural religion in terms of clan system. It began and flourished during the matriarchal clan society. During the late primitive society period, its ideology and rituals were fully established." Zhao (2010, p. 4) writes, "Shamanism is a polytheistic primitive religious belief and was produced during the matriarchal clan society."

James Frazer's (1854-1941) totemism (Frazer 1894) is not absent in Chinese ethnographic writings of Manchu shamanism. Fu and Meng (1991, p. 243) argue that the Willow worship among Manchus reflect the early matriarchal totemism. Wang (2002, pp. 6-7) believes that all eagle, raven, snake, and bear spirits in Manchu pantheon have totemic significance.

Ironically, concepts such as evolutionism, animism, primitivism, and totemism in Chinese ethnographic writings had been abandoned by Shirokogoroff in his Psychomental Complex of the Tungus published over eighty years ago (Shirokogoroff 1935). As Shirokogoroff states, "Perhaps the greatest theoretical hindrance to a successful investigation is a series of theories concerning classification of human groups into primitive, civilized, superior, inferior etc ... .Investigators among different ethnical groups have already brought so many facts which destroy the idea of 'primitiveness'" (Shirokogoroff 1935, p. 8).

When Chinese scholars hold that the Manchu shamanism has remained as "a remnant of the primitive culture" (Fu 2000, p. 124), at the same time, they see these "living fossils" as valuable cultural heritage and pay attentions on the conservation. In 1981, organized by Fu Yugaung and Shi Guangwei, the Institute of Ethnic Literature (IEL), Chinese Academy of Social Sciences (CASS) invited Manchu elders from the Shi clan in Jilin Province, including the amba shaman Shi Qingshan 石清山, the shaman's assistants Shi Qingmin 石清民and Shi Qingquan 石清泉 (Shi Guangwei's father), and Shi Guangwei to have a meeting with scholars in Beijing. Other two Manchu elders from Ningan County, Heilongjiang Province were also invited. Scholars and Manchu elders spent ten days working together at the institute. Information about Manchu shamanic cultures, dictated by the elders, were noted and 
videoed by scholars. One of the most important things in this event is that the Shi elders donated the clan ritual books to the institute ${ }^{6}$ (Fu 2015, pp. 215-16; and Song and Meng 1997, p. 36). During five days from 6 to 10 March 1987, Jinlin Provincial Art Comprehensive Office organized Shi clan shamans and other ritual participants to conduct a sacrificial rite including both domestic and wild rituals (Song and Meng 1997, pp. 37-39). The whole process was videoed and documented. Again, in March 1993, the Shi clan conducted a sacrificial rite in the request the Manchu Culture Society of Jilin City. The event resulted in a film titled as "The Shamanic Sacrifice of Chinese Manchu." It is worthy to note that the wild sacrifice was conducted by the domestic shamans and they all successfully fell into trance sate and were possessed by an ancestral shaman and animal spirits ${ }^{7}$. Song and Meng have commented on the motivation of the event, "The purpose of this investigation is to save, to excavate, to sort out, and to study the Manchu history, folklore, language, art, and the shamanic culture in order to enhance ethnic cultures, improve ethnic quality, and to prosper cultures of Chinese minorities'" (Song and Meng 1997, p. 40).

The lack of accessibility to anthropological training coupled with the constraints of politically defined research, have restrained Chinese scholars from delving deeply into a debate and consideration of these theories. During the period between the 1949 and 1980, shamanic and ritual practices were banned by the Chinese Government. During the course of the Cultural Revolution period (1966-1976), much of the Manchu shamans' paraphernalia and props for rites and rituals were destroyed or discarded in rivers (Fu 2015). After 1949, the field of ethnology developed in China was shaped heavily by theories of social evolution based on Marxism (Wang 1998). After 1980, Chinese government began to be tolerant of the folk religious practices. Manchu shamanism was thus revived in many clans. Scholars who conducted fieldwork among Manchus and other minorities in Manchuria in the 1980s and 1990s have rarely received anthropological trainings. For this reason, they were deeply influenced by evolutionary ideas.

\section{Conclusions}

Shirokogoroff's approach on Manchu and Tungus shamans has shaped the Western theoretical debates in anthropology of shamanism. Both Shirokogoroff and Eliade have seen trance as the central aspect of shamanism, although they have different understandings of the concept trance or ecstasy. This academic trend has been criticized for the way in which the social, historical, and political aspects have been neglected (Di Cosmo 1999; Humphrey 1994). In this paper, I have argued that the writing manner of "ethnographic realism" and the Western social context should be responsible for these problems in shamanism studies. Indeed, Shirokogoroff has realized the harmfulness of the Western context or the "the European complex" in his words (Shirokogoroff 1935, pp. 8-9). Yet, his psychomental complex built on Boas' historicism and Malinowski's functionalism does not go beyond the frame of the Western context.

The concept shaman or shamanism centered in human nervous systems and individualism is a product of the Western social tendency of universalism and homogenization. In contrast, Chinese scholars who are less influenced by the Western context have provided a distinctive paradigm in their ethnographic writings of Manchu shamanism. These writings are valuable to be potentials for us to rethink and rebuild the shamanism theory. However, as I have argued in this paper, the Chinese "non-Western" context, not different from the Western context, also represents knowledge hegemony to have shaped Chinese ethnographic writings. First, Chinese scholars' understandings of Manchu shamanism are rooted some evolutionary ideas such as primitivism and matriarchy, suggesting that

6 Six Shi Clan ritual books were collected. All of them are in Manchu language but noted by Chinese characters in terms of Manchu pronunciations. These books record the rituals, names of spirits, prayers, and chanting words (Shi and Liu 1992; Song 1993; Song and Meng 1997; Zhao 2010).

7 The last Amba shaman of the Shi clan is Shi Qingshan, who passed away in 1987 (Song and Meng 1997, p. 35). 
these existing Western concepts have been assimilated in the Chinese context. Second, Chinese writers have established authorities from the process of observations and writings.

From my analyses in this paper, we have realized that both Western context and Chinese "non-Western" context are problematic in writing ethnographic cultures. Marcus and Fischer have emphasized the importance of the dialogue in an active communicative process between anthropologists and the culture observed. Such a dialogue, in their argument, should be a "two-way and two-dimensional exchange" as interpretive processes "necessary both for communication internally within cultural system and externally between systems of meaning" (Marcus and Fischer 1986, p. 30). This two-way communitive dialogue is relevant to Geertz's juxtaposition of "experience-far" and "experience-near" (Geertz 1983, p. 57). In the same way, a dialogue as two-way and two-dimensional exchanges between Western experience and Chinese experience is one of the prerequisites in the reconstruction of the concepts shaman and shamanism.

Funding: This research received no external funding.

Acknowledgments: I am grateful to reviewers for their constructive comments. Thanks are also given to Paul Montgomery for his editing work.

Conflicts of Interest: The author declares no conflict of interest.

\section{References}

Astor-Aguilera, Miguel. 2014. Maya and Korean Pig Head Rituals: A Divergence from Eliade. Asian Journal of Latin American Studies 27: 1-29.

Boekhoven, Jeroen W. 2011. Genealogies of Shamanism: Struggles for Power, Charismas and Authority. Groningen: Barkhuis.

Di Cosmo, Nicola. 1999. Manchu Shamanic Ceremonies at the Qing Court. In State and Court Ritual in China. Edited by Joseph P. MeDermott. Cambridge: Cambridge University Press, pp. 352-98.

Eliade, Mircea. 1964. Shamanism: Archaic Techniques of Ecstasy. Princeton: Princeton University Press.

Elliott, Mark. 2001. The Manchu Way: The Eight Banners and Ethnic Identity in Late Imperial China. Stanford: Stanford University Press.

Frazer, James George. 1894. The Golden Bough. New York and London: MacMillan and Co.

$\mathrm{Fu}$, Yuguang. 1990. Samanjiao yu Shenhua 萨满教与神话. Shenyang: Liaoning Daxue Chubanshe.

$\mathrm{Fu}$, Yuguang. 2000. Saman Lun 萨满论. Shenyang: Liaoning Renmin Chubanshe.

Fu, Yuguang. 2005. Fu Yuguang Minsu Wenhua Lunji 富育光民俗文化论集. Changchun: Jilindaxue Chubanshe.

Fu, Yuguang. 2009. Saman Yishu Lun 萨满艺术论. Beijing: Xueyuan chubanshe.

Fu, Yuguang. 2014. Fuyuguang Shehui Diaocha Shouji 富育光社会调查手记. Beijing: Xueyuan Chubanshe.

Fu, Yuguang. 2015. Saman Wenhua Shouji 萨满文化手记. Bejing: Xueyuan Chibanshe.

Fu, Yuguang, and Shuyun Guo. 2005. Saman Wenhua Lun 萨满文化论. Taibei: Taiwan Xuesheng Shuju.

Fu, Yuguang, and Huiying Meng. 1991. Manzu Samanjiao Yanjiu 满族萨满教研究. Beijing: Beijing Daxue Chubanshe.

Fu, Yuguang, and Honggang Wang. 1995. Sanmanjiao Nüshen 萨满教女神. Shenyang: Liaoning Renmin Chubanshe. Fuchaxilu, Boyan. 2017. Aihui Shili Changjiang Suji 瑗珲十里长江俗记. Beijing: Xueyuan Chubanshe.

Geertz, Clifford. 1983. Local Knowledge: Further Essays in Interpretive Anthropology. New York: Basic Books.

Gibson, Todd. 1997. Notes on the History of the Shamanic in Tibet and Inner Asia. Numen 44: 39-59. [CrossRef]

Guo, Shuyun. 2001. Yuanshi Huotai Wenhua: Samanjiao Toushi 原始活态文化: 萨满教透视. Shanghai: Shanghai Guji Chubanshe.

Harner, Michael J. 1980. The Way of the Shaman: A Guide to Power and Healing. New York: Harper \& Row.

Hultkrantz, Åke. 1973. A definition of Shamanism. Temenos 9: 25-37.

Humphrey, Caroline. 1994. Shamanic Practices and the State in Northern Asia: Views from the Center and Periphery. In Shamanism, History, and the State. Edited by Nicholas Thomas and Caroline Humphrey. Ann Arbor: The University of Michigan Press, pp. 191-228.

Hutton, Ronald. 2001. Shamans: Siberian Spirituality and the Western Imagination. London and New York: Hambledon and London. 
Jiang, Xiaoli. 2016. Qinding Manzhou jishen jitian dianli dui manzu samanjiao guifan zuoyong de kaobian 《钦定 满州祭神祭天典礼》对满族萨满教规范作用的考辩. Shijie Zongjiao Wenhua 世界宗教文化 2: 94-99.

Jin, Qicong, and Jiasheng Zhang. 1992. Manzu Lishi yu Wenhua Jianbian 满族历史与文化简编. Shenyang: Liaoning Minzu Chubanshe.

Kehoe, Alice B. 1996. Eliade and Hultkrantz: The European Primitivism Tradition. American Indian Quarterly 20: 377-392. [CrossRef]

Kehoe, Alice B. 2000. Shamanism and Religion: An Anthropological Exploration in Critical Thinking. Long Grove: Waveland Press.

Klein, Cecelia F., Eulogio Guzmán, Elisa C. Mandell, and Maya Stanfield-Mazzi. 2002. The Role of Shamanism in Mesoamerican Art. Current Anthropology 43: 383-419. [CrossRef]

Layton, Robert. 1997. An Introduction to Theory in Anthropology. Cambridge: Cambridge University Press.

Lewis, Ioan M. 1971. Ecstasy Religion: A Study of Shamanism and Spirit Possession. Baltimore: Penguin Books.

Ling, Chunsheng. 1990. Songhuajiang Xiayou de Hezhezu 松花江下游的赫哲族. Shanghai: Shanghai Wenyi Chubanshe.

Marcus, George, and Dick Cushman. 1982. Ethnographies as Texts. Annual Review of Anthropology 11: $25-69$. [CrossRef]

Marcus, George, and Michael Fischer. 1986. Anthropology as Cultural Critique: An Experimental Moment in the Human Sciences. Chicago and London: The University of Chicago Press.

Mironov, Nikolai D., and Sergei Mikhailovich Shirokogoroff. 1924. Śramana-Shaman: Etymology of the Word "Shaman". Journal of the North China Branchof the Royal Asiatic Society 55: 105-30.

Morgan, Lewis H. 1887. Ancient Society. New York: Henry Holt \& Company.

Pedersen, Morten A. 2007. Talismans of Thought: Shamanist Ontologies and Extended Cognition in Northern Mogolia. In Thinking through Things: Theorising Artefacts Ethnographically. London: Routledge, pp. 141-66.

Roski, Evelyn. 1998. The Last Emperors: A Social History of Qing Imperial Institutions. Berkeley: University of California Press.

Said, Edward. 1978. Orientalism: Western Conceptions of the Orient. London: Routledge.

Shi, Guangwei, and Housheng Liu. 1992. Manzu Saman Tiaoshen 满族萨满跳神. Changchun: Jilin Wenshi Chubanshe.

Shi, Guangwei, Guiteng Liu, and Ruilan Ling. 2003. Manzu Yinyue Yanjiu 满族音乐研究. Beijing: Renmin Yinyue Chubanshe.

Shirokogoroff, Sergei Mikhailovich. 1935. Psychomental Complex of the Tungus. London: K. Paul, Trench, and Trubner.

Sidky, Homayun. 2010. Ethnographic Perspectives on Differentiating Shamans from other Ritual Intercessors. Asian Ethnology 69: 213-40.

Song, Heping. 1993. Manzu Saman Shege Yizhu 满族萨满神歌译注. Beijing: Shehui kexue chubanshe.

Song, Heping, and Huiying Meng. 1997. Manzu Saman Wenben Yanjiu 满族萨满文本研究. Taipei: Wunan Tushu Chuban Gongsi.

Sun, Jinji, and Hong Sun. 2010. Nüzhen minzushi 女真民族史. Guilin: Guangxi shifan daxue chubanshe.

Tylor, Edward B. 1924. Primitive Culture. New York: Brentano's Publishers. First published 1871.

Wallis, Robert J. 2009. Re-enchanting Rock Art Landscapes: Animic Ontologies, Nonhuman Agency and Rhizomic Personhood. The Journal of Archaeology, Consciousness and Culture 2: 47-70. [CrossRef]

Wallis, Robert J. 2013. Exorcizing "Spirits": Approaching "Shamans" and Rock Art Animically. In The Handbook of Contemporary Animism. Edited by Graham Harvey. Durham: Acumen, pp. 307-24.

Wang, Jianmin. 1998. Zhongguo Minzuxue Shi 中国民族学史. Kunming: Yunnan jiayu chubanshe.

Wang, Honggang. 2002. Manzu yu Saman Wenhua 满族与萨满文化. Beijing: Zhongyang Minzu Daxue Chubanshe. Yu, Yang, Hongzhen Guo, Jie Yuan, Huiying Meng, and Clan Shi. 2014. Manzu Shixing: Longnian Banpu yu Jisi Huodong Kaocha 满族石姓: 龙年办谱与祭祀活动考察. Beijing: Shehui Kexue Wenxian Chubanshe.

Zhao, Zhizhong. 2010. Manzu Saman Shenge Yanjiu 满族萨满神歌研究. Beijing: Minzu Chubanshe. Znamenski, Andrei A. 2007. The Beauty of the Primitive. Oxford: Oxford University Press.

(C) 2018 by the author. Licensee MDPI, Basel, Switzerland. This article is an open access article distributed under the terms and conditions of the Creative Commons Attribution (CC BY) license (http:/ / creativecommons.org/licenses/by/4.0/). 